\title{
On DSGE Models
}

\section{Lawrence J. Christiano* Martin S. Eichenbaum $^{\dagger} \quad$ Mathias Trabandt $^{\ddagger}$}

November 9, 2017

\begin{abstract}
Macroeconomic policy questions involve trade-offs between competing forces in the economy. The problem is how to assess the strength of those forces for the particular policy question at hand. One strategy is to perform experiments on actual economies. Unfortunately, this strategy is not available to social scientists. The only place that we can do experiments is in dynamic stochastic general equilibrium (DSGE) models. This paper reviews the state of DSGE models before the financial crisis and how DSGE modelers have responded to the crisis and its aftermath. In addition, we discuss the role of DSGE models in the policy process.
\end{abstract}

*Northwestern University, Department of Economics, 2211 Campus Drive, Evanston, Illinois 60208, USA. Phone: +1-847-491-8231. E-mail: l-christiano@northwestern.edu.

${ }^{\dagger}$ Northwestern University, Department of Economics, 2211 Campus Drive, Evanston, Illinois 60208, USA. Phone: +1-847-491-8232. E-mail: eich@northwestern.edu.

${ }^{\ddagger}$ Freie Universität Berlin, School of Business and Economics, Chair of Macroeconomics, Boltzmannstrasse 20, 14195 Berlin, Germany, E-mail: mathias.trabandt@gmail.com. 


\section{Introduction}

People who don't like dynamic stochastic general equilibrium (DSGE) models are dilettantes. By this we mean they aren't serious about policy analysis. Why do we say this? Macroeconomic policy questions involve trade-offs between competing forces in the economy. The problem is how to assess the strength of those forces for the particular policy question at hand. One strategy is to perform experiments on actual economies. This strategy is not available to social scientists. As Lucas (1980) pointed out roughly forty years ago, the only place that we can do experiments is in our models. No amount of a priori theorizing or regressions on micro data can be a substitute for those experiments. Dilettantes who only point to the existence of competing forces at work - and informally judge their relative importance via implicit thought experiments - can never give serious policy advice.

In this review, we discuss the state of DSGE models before the financial crisis and how modelers responded to the crisis and its aftermath. Inevitably, models must abstract from some features of the economy, raising the questions: which features should we include and which features should we exclude? With these questions in mind, we discuss what the key features of pre-financial crisis models were and what the rationale was for including those features. We then discuss how DSGE models evolved in response to the financial crisis and the Great Recession.

To illustrate how policy questions involve competing forces, we provide the following examples:

- Will an exchange rate depreciation stimulate an economy? On the one hand, conventional wisdom argues that a depreciation stimulates demand for domestic goods by reducing the price of exports and increasing the price of imports. On the other hand, a currency depreciation can reduce the demand for domestic goods if it reduces the net worth of firms, banks and households that have unhedged foreign debt. Which of these effects is stronger?

- What is the impact of tighter financial regulation on the economy? On the one hand, conventional wisdom argues that regulations reduce the likelihood of a financial crisis. On the other hand, regulations may reduce the level of economic activity by making it harder to obtain credit. Which of these effects is stronger?

- What is the impact of an increase in government spending? On the one hand, conventional wisdom argues that increases in government spending raise output by boosting demand. On the other hand, wealth effects and/or concerns about fiscal solvency could cause private spending to fall, thus reducing output. Which of these effects is stronger?

- Does an increase in unemployment benefits increase unemployment? On the one hand, conventional wisdom argues that higher benefits lead to higher wages and more unemployment. On the other hand, if the nominal interest rate is relatively insensitive to economic conditions, then the rise in wages raises inflation. The resulting decline in the real interest rate leads to higher aggregate demand, a rise in economic activity and lower unemployment. Which of these effects is stronger? 
- Does an increase in the nominal rate of interest increase or decrease inflation? On the one hand, conventional wisdom argues that higher interest rates reduce aggregate demand, output and inflation. On the other hand, higher interest rates raise borrowing costs, production costs and, hence, inflation. Higher debt servicing costs could also lead to higher inflation because the government prints money to cover its expenses. Which of these effects is stronger?

- Does increased wage flexibility mitigate recessions or make them worse? On the one hand, conventional wisdom suggests that falling wages increase the demand for labor, thereby increasing employment. On the other hand, falling wages shift income from workers to capitalists, thereby reducing aggregate demand and employment. Which effect is stronger?

In all of the above examples, the dilettante would be content to point out the existence of competing forces. But, policymakers at institutions like the International Monetary Fund are forced to assess their relative magnitude. DSGE models can and should play a central role in this assessment.

To be clear, when Madame Lagarde is briefed, she is not given the equations of a DSGE model or its impulse response functions. She is given a set of policy recommendations, and a rationale for each of them. She certainly understands that the recommendations are the result of a process in which layers of staff have worked with combinations of DSGE models, simple theoretical models and a-theoretical representations of the data. For her to take DSGE model-based recommendations seriously, the economic intuition underlying those recommendations has to be made in compelling and intuitive ways. What is true for Madame Lagarde is also true for the broader research community. To be convincing, it is critical for a DSGE modeler to understand and convey the economic intuition behind the model's implications in simple and intuitive terms. Inevitably, actual policymaking will always be to some extent an art. But even an artist needs a canvas to see the combined effect of the different colors. A DSGE model is that canvas.

In section 2 we review the state of mainstream DSGE models before the financial crisis and the Great Recession. In section 3 we describe how DSGE models are estimated and evaluated. Section 4 addresses the question of why DSGE modelers - like most other economists and policy makers - failed to predict the financial crisis and the Great Recession. Section 5 discusses how DSGE modelers responded to the financial crisis and its aftermath. Section 6 discusses how current DSGE models are actually used by policy makers. Section 7 offers concluding remarks.

In various sections we respond to some recent critiques of DSGE models. We focus on Stiglitz (2017) because his critique is a particularly egregious mischaracterization of the DSGE literature.

\section{Before The Storm}

In this section we describe early DSGE models and how they evolved prior to the crisis. 


\subsection{Early DSGE Models}

As a practical matter, people often use the term DSGE models to refer to quantitative models of growth or business cycle fluctuations. A classic example of a quantitative DSGE model is the Real Business Cycle (RBC) model associated with Kydland and Prescott (1982) and Long and Plosser (1983). These early RBC models imagined an economy populated by a representative consumer who operates in perfectly competitive goods, factor and asset markets. The one source of uncertainty in these models is a shock to technology. The representative consumer assumption can either be taken literally or reflect Gorman aggregation of heterogenous consumers who face idiosyncratic income shocks and complete asset markets. ${ }^{1}$ These models took the position that fluctuations in aggregate economic activity are an efficient response of the economy to exogenous shocks. ${ }^{2}$ The associated policy implications are clear: there was no need for any form of government intervention. In fact, government policies aimed at stabilizing the business cycle are welfare-reducing.

Excitement about RBC models crumbled under the impact of three forces. First, micro data cast doubt on some of the key assumptions of the model. These assumptions include, for example, perfect credit and insurance markets, as well as perfectly frictionless labor markets in which fluctuations in hours worked reflect movements along a given labor supply curve or optimal movements of agents in and out of the labor force (see Chetty et al. (2011)). Second, the models had difficulty in accounting for some key properties of the aggregate data, such as the observed volatility in hours worked, the equity premium, the low comovement of real wages and hours worked (see King and Rebelo (1999)). Open-economy versions of these models also failed to account for key observations such as the cyclical comovement of consumption and output across countries (see Backus et al. (1992)) and the extremely high correlation between nominal and real exchange rates (see Mussa (1986)). A closely affiliated failure was the model's inability to shed light on critical episodes like the recession associated with the Volcker disinflation. Third, the simple RBC model is mute on a host of policy-related issues that are of vital importance to macroeconomists and policy makers. Examples include: what are the consequences of different monetary policy rules for aggregate economic activity, what are the effects of alternative exchange rate regimes, and what regulations should we impose on the financial sector? ${ }^{3}$

\section{$2.2 \quad$ New Keynesian Models}

Prototypical pre-crisis DSGE models built upon the chassis of the RBC model to allow for nominal frictions, both in labor and goods markets. These models are often referred to as New Keynesian (NK) DSGE models. But, it would be just as appropriate to refer to them as Friedmanite DSGE models. The reason is that they embody the fundamental world view articulated in Friedman's seminal Presidential Address (see Friedman (1968)). According

\footnotetext{
${ }^{1}$ See e.g. Eichenbaum et al. (1982).

${ }^{2}$ Kydland and Prescott (1991) famously claimed that $70 \%$ of business cycle variation in output reflected the efficient response of the economy to technology shocks.

${ }^{3}$ It is certainly possible to introduce money into an RBC model via a cash-in-advance constraint or money in the utility function. But, the effects of monetary policy in these models is typically very small. See, for example, Cooley and Hansen (1989) or chapter 2 of Galí (2015).
} 
to this view, monetary policy has essentially no impact on output in the long run. ${ }^{4}$ But, monetary policy matters in the short run. Where Friedman and NK models differ is in what monetary policy they recommend. At the time, Friedman argued for a constant money growth rate rule. NK models typically call for activist monetary policy, where policymakers manage interest rates in response to shocks.

At a theoretical level, the importance of nominal frictions for business cycle analysis had been formally studied at least since the work of Calvo (1983), Fischer (1977) and Taylor (1980). Modern variants of those models were developed by Yun (1996) and Clarida et al. (1999) and Woodford (2003). A critical question was: what properties should quantitative versions of these models have?

The empirical literature of the time focused on the specific question: what are the effects of a disturbance to aggregate demand, say arising from a monetary policy shock? In a seminal paper Sims (1986) argued that one should identify monetary policy shocks with disturbances to a monetary policy reaction function in which the policy instrument is a short-term interest rate. ${ }^{5}$ Sims (1986), Bernanke and Blinder (1992) and Christiano et al. $(1996,1999)$ used vector autoregressions and orthogonalized innovations to the federal funds rate to estimate the effects of a shock to monetary policy. The consensus that emerged from this literature was that an expansionary monetary policy shock had many of the effects that Friedman (1968) had asserted in his Presidential Address. Specifically, an expansionary monetary policy shock corresponding to a decline in the U.S. federal funds rate led to humpshaped expansions in consumption, employment, investment, output and capital utilization as well as relatively small rises in inflation and real wages. Significantly, the peak effect of a monetary policy shock on economic activity occurrs well after the peak effect of the shock itself on the interest rate.

The VAR results are broadly consistent with mainstream interpretations of historical episodes. One example is Hume (1742)'s description of how money from the New World affected the European economy. The VAR results are also consistent with data on the Great Depression, according to which the earlier a country abandoned the Gold Standard, the sooner its recovery began (see Bernanke (1995)). These results are also consistent with the view that countries which abandoned the quasi-fixed exchange mechanism in early 1992 fared better than those who did not.

\subsection{CEE Model}

While the VAR results certainly are subject to challenge (see for example Ramey (2016)), we believe it is fair to characterize them as capturing the conventional wisdom about the effects of a shock to aggregate demand. A key challenge was to develop a version of the NK model that could account quantitatively for those effects.

Christiano et al. (2005) (henceforth CEE) developed a version of the NK model that met this challenge. We go into some detail describing the basic features of that model because they form the core of leading pre-crisis DSGE models, such as Smets and Wouters (2003, 2007).

\footnotetext{
${ }^{4}$ Of course, this statement is not meant to apply to hyperinflation episodes.

${ }^{5}$ Previous authors like Barro (1978) had identified shocks to monetary policy with unanticipated movements in various monetary aggregates.
} 
As in early RBC models, the model economy in CEE is populated by a representative household and asset markets are complete. In contrast to RBC models, goods markets and labor markets are not perfectly competitive. This departure is necessary to allow for sticky prices and sticky nominal wages - if a price or wage is sticky, someone has to choose it.

In CEE, nominal rigidities arise from Calvo (1983) style frictions. In particular, firms and households can change prices or wages with some exogenous probability. In addition, they must satisfy whatever demand materializes at those prices and wages.

Calvo-style frictions make sense only in environments where inflation is moderate. Even in moderate inflation environments, Calvo style frictions have implications that are inconsistent with aspects of micro data. Still, its continued use reflects the fact that Calvo-style frictions allow models to capture, in an elegant and tractable manner, what many researchers believe is an essential feature of business cycles. In particular, for moderate inflation economies, firms and labor suppliers typically respond to variations in demand by varying quantities rather than prices.

CEE build features into the model which ensure that firms' marginal costs are nearly a-cyclical. They do so for three reasons. First, there is substantial empirical evidence in favor of this view (see for example, Anderson et al. (2017)). Second, the more a-cyclical marginal cost is, the more plausible is the assumption that firms satisfy demand. Third, as in standard NK models, inflation is an increasing function of current and expected future marginal costs. So, relatively a-cyclical marginal costs are critical for dampening movements in the inflation rate.

The CEE model incorporates two mechanisms to ensure that marginal costs are relatively a-cyclical. The first is the sticky nominal wage assumption mentioned above. The second mechanism is that the rate at which capital is utilized can be varied in response to shocks.

\subsubsection{Consumption}

To generate appropriately signed hump-shaped responses of aggregate quantities to a monetary policy shock, CEE introduce two key perturbations to the real side of the model. First, they assume habit-formation in consumption. This assumption captures a variety of frictions that induce inertial behavior in consumption. It also remedies a first-order problem that prototypical RBC models and NK models share. In both cases, the representative consumer can borrow and lend at the risk free real interest rate, so that the following Euler equation holds

$$
1=\beta E_{t}\left[\frac{U^{\prime}\left(C_{t+1}\right)}{U^{\prime}\left(C_{t}\right)} r_{t}\right]
$$

Here $E_{t}$ denotes the conditional expectations operator, $U^{\prime}\left(C_{t}\right)$ denotes the marginal utility of consumption and $r_{t}$ denotes the date $t+1$ realized one-period real interest rate on a nominal bond. Models in which (1) holds have difficulty accounting for VAR-based evidence which suggests that an expansionary monetary policy shock triggers (i) a hump-shaped positive response in consumption and (ii) a persistent reduction in the real rate of interest. To see the problem with (1) it is useful to abstract from uncertainty and suppose that $U\left(C_{t}\right)=\ln \left(C_{t}\right)$. Then, (1) implies that $r_{t}=C_{t+1} /\left(\beta C_{t}\right)$. So, a decrease in $r_{t}$ is associated with a downward 
trajectory in consumption over time. This response pattern is completely at odds with the VAR evidence, according to which consumption slowly rises and then falls.

The actual hump-shape response pattern of consumption implies that the time derivative of consumption jumps at the time of an expansionary monetary policy shock and then declines. To account for this pattern, CEE introduce habit formation in consumption. This change amounts to replacing $C_{t}$ by its (quasi) time derivative in the Euler equation. In that case, the model correctly predicts that when $r_{t}$ falls the time derivative of consumption also falls. ${ }^{6}$ See Christiano et al. (2010) for an extended discussion of this point. Habit formation is appealing as a way to make the model consistent with the VAR evidence because there is evidence from the finance and growth literature suggesting its importance. ${ }^{7}$

It has been known for decades that restrictions like (1) can be rejected, even in representative agent models that allow for habit formation. ${ }^{8}$ So, why would anyone ever use the representative agent assumption? In practice analysts have used that assumption because they think that for many questions they get roughly the right answer. For example, the answer that the standard DSGE model gives to monetary policy questions hinges on a key property: a policy induced cut in the interest rate leads to an increase in consumption. In section 5 we discuss recent work on heterogeneous agent DSGE models and report that those models have precisely this property. So, for many monetary policy questions the representative agent model can be thought of as a useful reduced-form way of capturing the implications of these more realistic, micro-founded models.

\subsubsection{Investment}

Absent adjustment costs, DSGE models imply that investment is counterfactually volatile. To deal with this issue and to induce a hump-shaped response of investment to a monetary policy shock, CEE suppose that there are costs to changing the rate of investment. With this assumption, a quick rise in investment from past levels is expensive. That is why, in CEE, the investment response to a monetary policy shock is hump-shaped.

An important alternative specification of adjustment costs penalizes changes in the capital stock. This specification has a long history in macroeconomics, going back at least to Lucas and Prescott (1971). CEE show that with this type of adjustment cost, investment jumps after an expansionary monetary policy shock and then converges monotonically back to its pre-shock level from above. This response pattern is inconsistent with the VAR evidence.

There are additional reasons to prefer the specification which penalizes changes in investment rather than capital. Lucca (2006) and Matsuyama (1984) provide interesting theoretical foundations that rationalize the investment adjustment cost specification. More recently, Eberly et al. (2012) show that the specification of investment adjustment costs proposed by CEE accounts for the fact that lagged-investment is an important predictor of current and

\footnotetext{
${ }^{6}$ There is a nuance that we have glossed over. The language in the text implicitly assumes what is referred to as external habit in consumption while CEE assume internal habit in consumption. In practice, the quantitative distinction for business cycle models between the two types of habit is very small.

${ }^{7}$ In the finance literature see, for example, Eichenbaum and Hansen (1990a), Constantinides (1990) and Boldrin et al. (2001). In the growth literature see Carroll et al. (1997, 2000). In the psychology literature, see Gremel et al. (2016).

${ }^{8}$ See Dunn and Singleton (1986) and Eichenbaum and Hansen (1990b).
} 
future investment. They also show that a generalized version of their model is consistent with the behavior of firm-level data. ${ }^{9}$

\subsection{Financial Frictions and Pre-Crisis DSGE Models}

Authors like Stiglitz (2017) have asserted that pre-crisis DSGE models did not allow for financial frictions, liquidity constrained consumers, or a housing sector. That criticism is certainly true of CEE. But, it is not true for the pre-crisis DSGE literature as a whole. We now discuss some leading pre-crisis DSGE models that constitute concrete counter examples to Stiglitz's claim.

Galí et al. (2007) investigate the implications of the assumption that some consumers are liquidity constrained. Specifically, they assume that a fraction of households cannot borrow at all. They then assess how this change affects the implications of DSGE models for the effects of a shock to government consumption. Not surprisingly, they find that liquidity constraints substantially magnify the impact of government spending on GDP. In many ways this paper set the stage for the heterogeneous agent NK models discussed in section 5 .

Building on a large theoretical literature, Carlstrom and Fuerst (1997) and Bernanke et al. (1999) develop DSGE models that incorporate credit market frictions. In both models, firms' ability to borrow is limited by the value of their net worth. Consequently, the models exhibit a "financial accelerator" in which credit markets work to amplify and propagate shocks to the macroeconomy.

Christiano et al. (2003) add several features to the CEE model. First, they incorporate the fractional reserve banking model developed by Chari et al. (1995). Second, they allow for financial frictions as modeled by Bernanke et al. (1999). Finally, they assume that agents can only borrow using nominal non-state contingent debt, so that the model incorporates the Fisherian debt deflation channel. Christiano et al. (2003) use their model to quantitatively study the cause of the Great Depression and why it lasted so long.

Finally we note that Iacoviello (2005) develops and estimates a DSGE model with nominal loans and collateral constraints tied to housing values. This paper is an important antecedent to the large post-crisis DSGE literature on the aggregate implications of housing market booms and busts.

\section{How DSGE Models Are Estimated and Evaluated}

In this section, we discuss how DSGE models are solved, estimated and evaluated. We focus, for the most part, on approaches based on linear approximations of DSGE model solutions. Section 5.2 discusses the econometric analysis of nonlinear approximations to models, a phenomenon that has become more prevalent since the crisis.

Prior to the financial crisis, researchers generally worked with log-linear approximations to the equilibria of DSGE models. There were three reasons for this choice. First, for the models being considered and for the size of shocks that seem relevant for the post-war

\footnotetext{
${ }^{9}$ The Eberly et al. (2012) conclusions are consistent with those of an important earlier paper. Topel and Rosen (1988) argue that data on housing construction are best understood using a cost function that penalizes changes in the flow of housing construction.
} 
US data, linear approximations seemed very accurate. ${ }^{10}$ Second, linear approximations allow researchers to exploit the large array of tools for forecasting, filtering and estimation provided in the literature on linear time series analysis. Third, it was simply not computationally feasible to solve and estimate large, nonlinear DSGE models. The technological constraints were real and binding.

Researchers choose values for the key parameters of their models using a variety of strategies. In some cases, researchers choose parameter values to match unconditional model and data moments, or they reference findings in the empirical micro literature. This procedure is called calibration, and does not use formal sampling theory. Calibration was the default procedure in the early RBC literature and it is also sometimes used in the DSGE literature. ${ }^{11}$

Most of the modern DSGE literature conducts inference about parameter values and model fit using one of two strategies that make use of formal econometric sampling theory. The first strategy is limited information because it does not exploit all of the model's implications for moments of the data. One variant of the strategy minimizes the distance between a subset of model-implied second moments and their analogs in the data. A more influential variant of this first strategy estimates parameters by minimizing the distance between model and data impulse responses to economic shocks. ${ }^{12}$ One way to estimate the data impulse response functions is based on partially identified VARs. Another variant of this strategy, sometimes referred to as the method of external instruments, involves using historical or narrative methods to obtain instruments for the underlying shocks. ${ }^{13}$ Finally, researchers have exploited movements in asset prices immediately after central bank policy announcements to identify monetary policy shocks and their consequences. This approach is referred to as high frequency identification. ${ }^{14}$

The initial limited information applications in the DSGE literature used generalized method of moments estimators and classical sampling theory (see Hansen (1982)). Building on the work of Chernozhukov and Hong (2003), Christiano et al. (2010) showed how the Bayesian approach can be applied in limited information contexts. ${ }^{15}$

A critical advantage of the Bayesian approach is that one can formally and transparently bring to bear information from a variety of sources on what constitutes "reasonable" values for model parameters. Suppose, for example, that one could only match the dynamic response to a monetary policy shock for parameter values implying that firms change their prices on average every two years. This implication is strongly at variance with evidence from micro data. ${ }^{16}$ In the Bayesian approach, the analyst would impose priors that sharply penalize such parameter values. So those parameter values would be assigned low probabilities in the analyst's posterior distribution. Best practice compares priors and posteriors for parameters. This comparison allows the analyst to make clear the role of priors and the data in generating the results.

\footnotetext{
${ }^{10}$ See for example the papers in Taylor and Uhlig (1990).

${ }^{11}$ See for example Galí et al. (2007).

${ }^{12}$ Examples of the impulse response matching approach include CEE, Altig et al. (2011), Iacoviello (2005) and Rotemberg and Woodford (1991).

${ }^{13}$ See Mertens and Ravn (2013) who use this method to identify exogenous changes to fiscal policy.

${ }^{14}$ Early contributions include e.g. Kuttner (2001) and Gürkaynak et al. (2005).

${ }^{15}$ Examples of applications include Christiano et al. (2016) and Hofmann et al. (2012).

${ }^{16}$ See for example Nakamura and Steinsson (2008) or Eichenbaum et al. (2011).
} 
The second strategy for estimating DSGE models involves full-information methods. In many applications, the data used for estimation is relatively uninformative about the value of some of the parameters in DSGE models (see Canova and Sala (2009)). A natural way to deal with this fact is to bring other information to bear on the analysis. Bayesian priors are a vehicle for doing exactly that. ${ }^{17}$ This is an important reason why the Bayesian approach has been very influential in full-information applications. Starting from Smets and Wouters (2003), an large econometric literature has expanded the Bayesian toolkit to include better ways to conduct inference about model parameters and to analyze model fit. ${ }^{18}$

Not all estimation strategies before the crisis were based on model linearization. For example, in their estimation of a model for the Great Depression, Christiano and Davis (2006) report evidence that linear approximations involve significant approximation error for the magnitude of shocks appropriate to that dataset. They show that a second-order approximation performs much better and they adopt a nonlinear estimation strategy based on the unscented Kalman filter described in Wan and van der Merwe (2001).

We conclude this section by responding to some recent critiques of econometric practice with DSGE models. We focus on Stiglitz (2017) because his critique is a particularly egregious mischaracterization of empirical work in the DSGE literature. Stiglitz claims that "Standard statistical standards are shunted aside [by DSGE modelers]." As evidence, he cites four points from what he refers to as Korinek (2017)'s "devastating critique" of DSGE practitioners.

The first point is:

"...the time series employed are typically detrended using methods such as the HP filter to focus the analysis on stationary fluctuations at business cycle frequencies. Although this is useful in some applications, it risks throwing the baby out with the bathwater as many important macroeconomic phenomena are non-stationary or occur at lower frequencies. An example of particular relevance in recent years are the growth effects of financial crises." Stiglitz (2017, page 3).

Neither Stiglitz nor Korinek offer any constructive advice on how to address the difficult problem of dealing with nonstationary data. In sharp contrast, the DSGE literature struggles mightily with this problem and adopts different strategies for modeling non-stationarity in the data.

As a matter of fact, Stiglitz and Korinek's first point is simply incorrect. The vast bulk of the modern DSGE literature does not estimate models using HP filtered data. Instead, the literature proceeds as follows. Researchers include a specification of the sources of non-stationarity in their model. Their estimation procedure then makes efficient use of the features of the data that, from the perspective of the model, are most informative for estimation and testing. So, from this point of view, the focus is on the babies in the bath water.

DSGE models of endogenous growth provide a particularly stark counterexample to Korinek and Stiglitz's claim that modelers focus the analysis on stationary fluctuations at

\footnotetext{
${ }^{17}$ See Christiano et al. (2010) for a discussion of limitations in the standard approach to constructing Bayesian priors and some proposed improvements.

${ }^{18}$ For a recent survey see Fernández-Villaverde et al. (2016).
} 
business cycle frequencies. For example, Comin and Gertler (2006) begin with the observation that many industrialized countries exhibit episodes of sustained high and low growth that are longer than the usual business cycle booms and recessions. They refer to these episodes as medium-term business cycles. They argue that conventional filters like the HP filter, which emphasizes business cycle frequencies, sweeps medium-term business cycles into the trend. Their paper is devoted to empirically characterizing and modeling the mediumterm cycles and their connection to business cycles. Comin and Gertler's analysis (published before the financial crisis) and the literature that follows, demonstrate that the first claim by Korinek and Stiglitz is simply false.

Second, Stiglitz reproduces Korinek (2017)'s assertion:

“.... for given detrended time series, the set of moments chosen to evaluate the model and compare it to the data is largely arbitrary-there is no strong scientific basis for one particular set of moments over another". Stiglitz (2017, page 3$)$.

Third, Stiglitz also reproduces the following assertion by Korinek (2017):

"... for a given set of moments, there is no well-defined statistic to measure the goodness of fit of a DSGE model or to establish what constitutes an improvement in such a framework". Stiglitz (2017, page 4).

Both of these assertions amount to the claim that classical maximum likelihood and Bayesian methods as well as GMM methods are unscientific. This view should be quite a revelation to the statistics and econometrics community.

Finally Stiglitz reproduces Korinek (2017)'s assertion:

"DSGE models frequently impose a number of restrictions that are in direct conflict with micro evidence." Stiglitz (2017, page 4).

All models - including those advocated by Stiglitz - are inconsistent with some aspects of micro evidence. This is hardly news. As we stressed, the Bayesian approach allows one to bring to bear information culled from micro data on model parameters. At a deeper level, micro data influences, in a critical but slow moving manner, the class of models that we work with. Our discussion of the demise of the pure RBC model is one illustration of this process. The models of financial frictions and heterogeneous agents discussed below are an additional illustration of how DSGE models evolve over time in response to micro data (see sections 5.1 and 5.3$)$.

\section{Why Didn't DSGE Models Predict the Financial Crisis?}

Pre-crisis DSGE models didn't predict the increasing vulnerability of the US economy to a financial crisis. They have also been criticized for not placing more emphasis on financial frictions. Here, we give our perspective on these failures. 
There is still an ongoing debate about the causes of the financial crisis. Our view, shared by Bernanke (2009) and many others, is that the financial crisis was precipitated by a rollover crisis in a very large and highly levered shadow-banking sector that relied on short-term debt to fund long-term assets. ${ }^{19}$

The trigger for the rollover crisis was developments in the housing sector. U.S. housing prices had risen rapidly in the 1990's with the S\&P/Case-Shiller U.S. National Home Price Index rising by a factor of roughly 2.5 between 1991 and 2006. The precise role played by expectations, the subprime market, declining lending standards in mortgage markets, and overly-loose monetary policy is not critical for our purposes. What is critical is that housing prices began to decline in mid-2006, causing a fall in the value of the assets of shadow banks that had heavily invested in mortgage-backed securities. The Fed's willingness to provide a safety net for the shadow banking system was at best implicit, creating the conditions under which a roll-over crisis was possible. In fact a rollover crisis did occur and shadow banks had to sell their asset-backed securities at fire-sale prices, precipitating the Great Recession.

Against this background, we turn to the first of the two criticisms of DSGE models mentioned above, namely their failure to signal the increasing vulnerability of the U.S. economy to a financial crisis. This criticism is correct. The failure reflected a broader failure of the economics community. The overwhelming majority of academics, regulators and practitioners did not realize just how large the shadow banking sector was and how vulnerable it was to a run. The widespread belief was that if a country had deposit insurance, bank runs were a thing of the past. The failure was to allow a small shadow-banking system to metastasize into a massive, poorly-regulated wild west-like sector that was not protected by deposit insurance or lender-of-last-resort backstops.

We now turn to the second criticism of DSGE models, namely that they did not sufficiently emphasize financial frictions. In practice modelers have to make choices about which frictions to emphasize. One reason why modelers did not emphasize financial frictions in DSGE models is that until the recent crisis, post-war recessions in the U.S. and Western Europe did not seem closely tied to disturbances in financial markets. The Savings and Loans crisis in the US was a localized affair that did not grow into anything like the Great Recession. Similarly, the stock market meltdown in the late 1980's and the bursting of the tech-bubble in 2001 only had minor effects on aggregate economic activity.

At the same time, the financial frictions that were included in DSGE models did not seem to have very big effects. Consider, for example, Bernanke et al. (1999)'s (BGG) influential model of the financial accelerator. That model is arguably the most influential pre-crisis DSGE model with financial frictions. It turns out that the financial accelerator has only a modest quantitative effect on the way the model economy responds to shocks, see e.g. Linde et al. (2016). In the same spirit, Kocherlakota (2000) argues that models with Kiyotaki and Moore (1997) (KM)-type credit constraints have only negligible effects on dynamic responses to shocks. Finally, Brzoza-Brzezina and Kolasa (2013) compare the empirical performance of the standard New Keynesian DSGE model with variants that incorporate KM and BGG type constraints. Their key finding is that neither model substantially improves on the

\footnotetext{
${ }^{19}$ Shadow banks are financial entities other than regulated depository institutions that serve as intermediaries to channel savings into investment. Securitization vehicles, asset backed commercial paper vehicles, money market funds, investment banks, mortgage companies, and a variety of other entities are part of the shadow banking system (see Bernanke (2010)).
} 
performance of the benchmark model, either in terms of marginal likelihoods or impulse response functions. So, guided by the post-war data from the U.S. and Western Europe, and experience with existing models of financial frictions, DSGE modelers emphasized other frictions.

In sum, the pre-crisis mainstream DSGE models failed to forecast the financial crisis because they did not integrate the shadow banking system into their analysis. In the next section we discuss how modelers have responded to this shortcoming and others.

\section{After the Storm}

Given the data-driven nature of DSGE enterprise, it is not surprising that the financial crisis and its aftermath had an enormous impact on DSGE models. In this section we discuss the major strands of work in post-financial crisis DSGE models. We then assess recent critiques of DSGE models in light of these developments. As above we focus on Stiglitz (2017).

\subsection{Financial Frictions}

The literature on financial frictions can loosely be divided between papers that focus on frictions originating inside financial institutions and those that arise from the characteristics of the people who borrow from financial institutions. Theories of bank runs and rollover crisis focus on the first class of frictions. Theories of collateral constrained borrowers focus on the second class of frictions.

We do not have space to systematically review the DSGE models that deal with both types of financial frictions. Instead, we discuss one example of each, beginning with work that emphasizes the first type of friction.

Motivated by events associated with the financial crisis, Gertler and Kiyotaki (2015) and Gertler et al. (2016) (GKP) develop a DSGE model of a rollover crisis in the shadow banking sector, which triggers fire sales. The resulting decline in asset values tightens balance sheet constraints in the rest of the financial sector and throughout the economy. ${ }^{20}$ In this model, shadow banks buy long-term assets using short-term debt. As liabilities come due, shadow banks must either persuade creditors to roll over short-term debt or they must sell assets. There is always an equilibrium in the model in which shadow banks can roll over the shortterm debt. But, creditors also consider the possibility that there will be a rollover crisis in which the shadow banking system cannot renew its short-term debt. In that event, the shadow banking system as a whole must sell long-term assets. The only potential buyers of those assets are other agents who have little experience evaluating them. In this state of the world, agency problems associated with asymmetric information become important so that potential buyers are only willing to pay a small amount for the assets. That is, the assets must be sold at fire sale prices. If creditors think that banks' net worth will be positive in this scenario, then a rollover crisis is impossible. However, if banks' net worth is negative in this scenario then a rollover crisis can occur.

\footnotetext{
${ }^{20}$ The key theoretical antecedent is the bank run model of ? and the sovereign debt rollover crisis of Cole and Kehoe (2000).
} 
Figure 1: Balance Sheet of the Shadow-Banking Sector Before and After the Housing Market Correction

\section{Pre-housing market correction}

\begin{tabular}{|c|l|}
\hline Assets & Liabilities \\
\hline $120(105)$ & Deposits: 100 \\
\hline & Banker net worth $20(5)$ \\
\hline
\end{tabular}

\section{Post-housing market correction}

\begin{tabular}{|c|l|}
\hline Assets & Liabilities \\
\hline $110(95)$ & Deposits: 100 \\
\hline & Banker net worth $10(-5)$ \\
\hline
\end{tabular}

We use this model to illustrate how a relatively small shock can trigger a system-wide rollover crisis in the shadow banking system. To this end, consider Figure 1, which captures in a highly stylized way the key features of the shadow-banking system before (left side) and after (right side) the crisis. In the left-side table the shadow banks' assets and liabilities are 120 and 100, respectively. So, their net worth is positive. The numbers in parentheses are the value of the assets and net worth of the shadow banks in the case of a rollover crisis and fire-sale of assets. GKP assume that the probability of a crisis is proportional to the amount creditors would lose in the event of a rollover crisis. So, in this example a rollover crisis cannot occur.

Now imagine that the assets of the shadow banks decline for fundamental reasons. Here, we have in mind the events associated with the decline in housing prices that began in the summer of 2006. The right side of Figure 1 is the analog of the left side, taking into account the lower value of the shadow banks' assets. In the example, the market value of assets has fallen by 10, from 120 to 110. In the absence of a rollover crisis, the system is solvent. However, the value of the assets in the case of a rollover crisis is 95 and the net worth of the bank is negative in that scenario. So, a relatively small change in asset values triggers a positive probability of a rollover crisis. This example captures in a simple way how a small shock can give rise to a financial crisis.

The example also illustrates the importance of embedding simple insights into a DSGE model. Consider, for example, the number 95 in the table representing the value of bank assets. That number is critical to any assessment of the vulnerability of the economy to a financial crisis. But, that number depends critically on the overall structure of the economy and is an equilibrium outcome of a crisis. It is hard to imagine how one would estimate that number without using a DSGE model.

We now turn to our second example, which focuses on frictions that arise from the characteristics of the people who borrow from financial institutions. Using an estimated DSGE model, Christiano et al. (2014) (CMR) argue that because of financial frictions, risk shocks have been the dominant source of US business cycles, at least in the past three decades. By risk shocks, they mean disturbances to the variance of idiosyncratic shocks to non-financial firms' technologies. Absent financial frictions, risk shocks would have no impact on economic aggregates.

But, in the CMR model, firms' creditors cannot costlessly observe the realization of a 
firm's idiosyncratic technology shock. As in BGG, CMR assume that firms borrow from their creditors to finance investment using standard debt contracts. In this environment a rise in risk leads to an increase in the spread between the interest rate at which firms borrow and the risk-free rate. That rise is accompanied by a decline in borrowing and aggregate investment. In the presence of nominal rigidities, the fall in aggregate demand leads to a recession and a decline in the stock market.

CMR estimate their model using data on 12 aggregate time series that include data on financial variables like the stock market and interest rate spreads. Using the estimated model, they estimate the importance of different shocks for U.S. business cycles. They conclude that risk shocks have been the major source of U.S. business cycles.

Critics of DSGE models have argued that technology shocks are inherently implausible as a source of business cycles. ${ }^{21}$ It is true that pre-financial crisis DSGE models like Smets and Wouters (2007) attribute roughly 60 percent of the business cycle variation in GDP to neutral and investment-specific technology shocks. In sharp contrast, CMR attribute only 15 percent of that variation to those shocks. ${ }^{22}$

It is widely believed that the housing sector played an important role in the financial crisis and its aftermath. Not surprisingly, there has been an enormous amount of research on the housing sector since the financial crisis. We cannot review this literature here. But, we do want to emphasize that DSGE modelers have responded by developing models in which the housing sector plays an important role in business cycles. The first prominent example is Liu et al. (2013), who use a DSGE model to study the interaction of land and housing prices over the business cycle. In their model, the value of firms' land and capital constrains how much they can borrow.

Building on Iacoviello (2005), Iacoviello and Neri (2010) study the importance of shocks to the housing sector in an estimated DSGE model where the value of housing constrains household borrowing. Berger et al. (2017) develop models with financial frictions to analyze the response of consumption to changes in housing prices.

We conclude this section by returning to Stiglitz's critique that DSGE models do not include financial frictions. Stiglitz (2017, p. 12) writes:

"...an adequate macro model has to explain how even a moderate shock has large macroeconomic consequences."

Evidently, he has not read GKP, in which even a moderate shock has important consequences. Stiglitz (2017, p. 10) also writes:

"...in standard models the money demand equation is supposed to summarize all that is relevant for finance; and, indeed, not even that is very relevant - all that matters is that somehow the central bank is able to control the interest rate. But, the interest rate is not the interest rate confronting households and firms; the spread between the two is a critical endogenous variable."

\footnotetext{
${ }^{21}$ See Stiglitz (2017, p. 5).

${ }^{22}$ Smets and Wouters (2007) do not report the contribution of shocks to the business cycle. We calculated the 60 percent number in the text using their results for the forecast error variances at the 10-quarter ahead horizon (see their Figure 1). That horizon corresponds to business cycle frequencies. CMR obtain the same results when they re-estimate their model dropping the risk shock and all financial frictions and computing the relevant numbers based on business cycle frequencies (see CMR, table 5).
} 
Evidently, Stiglitz has not read post-crisis papers like CMR. In CMR, money demand has indeed been rendered irrelevant by the monetary authority's interest rate rule. Nevertheless, credit and the endogenous spread between the interest rates confronting households and firms play central roles in the analysis.

\subsection{Zero Lower Bound and Other Nonlinearities}

The financial crisis and its aftermath was associated with two important nonlinear phenomena. The first phenomenon was the rollover crisis in the shadow-banking sector discussed above. The GKP model illustrates the type of nonlinear model required to analyze this type of crisis. The second phenomenon was that the nominal interest rate hit the zero lower bound (ZLB) in December 2008. An earlier theoretical literature associated with Krugman (1998), ? and Woodford and Eggertsson (2003) had analyzed the implications of the ZLB for the macroeconomy. Building on this literature, DSGE modelers quickly incorporated the ZLB into their models and analyzed its implications.

In what follows, we discuss one approach that DSGE modelers took to understand what triggered the Great Recession and why it persisted for so long. We then review some of the policy advice that emerged from DSGE models.

\section{The Causes of the Crisis and Slow Recovery}

One set of papers uses detailed DSGE models to assess which shocks triggered the financial crisis and what propagated their effects over time. We focus on two papers to give the reader a flavor of this literature. Christiano et al. (2016) (CET) estimated a linearized DSGE model using pre-crisis data, in a version of their model that ignores the possibility that the ZLB could bind. For the post-crisis period, CET take into account that the ZLB was binding. In addition, they take into account the Federal Reserve's guidance about the circumstances in which monetary policy would return to normal. Initially, that guidance took the form of a time-dependent rule. But in 2011 that guidance became dependent on endogenous variables like inflation and the unemployment rate. The resulting model and solution are highly nonlinear in nature.

CET argue that the bulk of movements in aggregate real economic activity during the Great Recession was due to financial frictions interacting with the ZLB. At the same time, their analysis indicates that the observed fall in total factor productivity and the rise in the cost of working capital played important roles in accounting for the small size of the drop in inflation that occurred during the Great Recession.

Gust et al. (2017) estimate, using Bayesian methods, a fully non-linear DSGE model with an occasionally binding ZLB. In contrast to CET, their estimation period includes data from the pre- and post-crisis periods. They solve the model using nonlinear projection methods. Because the model is nonlinear, the likelihood of the data is not normal, and they approximate the likelihood using the particle filter. Gust et al. (2017) show that the nonlinearities in the model play an important role for inference about the source and propagation of shocks. According to their analysis, shocks to the demand for risk-free bonds and, to a lesser extent, the marginal efficiency of investment proxying for financial frictions, played a critical role in the crisis and its aftermath. 
A common feature of the previous papers is that they provide a quantitatively plausible model of the behavior of major economic aggregates during the Great Recession when the ZLB was a binding constraint. Critically, those papers include both financial frictions and nominal rigidities. A model of the crisis and its aftermath which didn't have financial frictions just would not be plausible. At the same time, a model that included financial frictions but didn't allow for nominal rigidities would have difficulty accounting for the broad-based decline across all sectors of the economy. Such a model would predict a boom in those sectors of the economy that are less dependent on the financial sector.

The fact that DSGE models with nominal rigidities and financial frictions can provide quantitatively plausible accounts of the financial crisis and the Great Recession makes them obvious frameworks within which to analyze alternative fiscal and monetary policies. We begin with a discussion of fiscal policy.

\section{Fiscal Policy}

In standard DSGE models, an increase in government spending triggers a rise in output and inflation. When monetary policy is conducted according to a standard Taylor rule that obeys the Taylor principle, a rise in inflation triggers a rise in the real interest rate. Other things equal, the policy-induced rise in the real interest rate lowers investment and consumption demand. So, in these models the government spending multiplier is typically less than one. But when the ZLB binds, the rise in inflation associated with an increase in government spending does not trigger a rise in the real interest rate. With the nominal interest rate stuck at zero, a rise in inflation lowers the real interest rate, crowding consumption and investment in, rather than out. This raises the quantitive question; how does a binding ZLB constraint on the nominal interest rate affect the size of the government spending multiplier?

Christiano et al. (2011) (CER) address this question in a DSGE model, assuming all taxes are lump-sum. A basic principle that emerges from their analysis is that the multiplier is larger the more binding is the ZLB. CER measure how binding the ZLB is by how much a policymaker would like to lower the nominal interest below zero if he or she could. For their preferred specification, the multiplier is much larger than one. ${ }^{23}$ When the ZLB is not binding, then the multiplier would be substantially below one.

Erceg and Lindé (2014) examine the impact of distortionary taxation on the magnitude of government spending multiplier in the ZLB. They find that the results based on lump-sum taxation are robust relative to the situation in which distortionary taxes are raised gradually to pay for the increase in government spending.

There is by now a large literature that studies the fiscal multiplier when the ZLB binds using DSGE models that allow for financial frictions, open-economy considerations and liquidity constrained consumers. We cannot review this literature because of space constraints. But, the crucial point is that DSGE models are playing an important role in the debate among academics and policymakers about whether and how fiscal policy should be used to fight recessions. We offer two examples in this regard. First, Coenen et al. (2012) analyze the impact of different fiscal stimulus shocks in several DSGE models that are used by policymaking institutions. The second example is Blanchard et al. (2017) who analyze the effects of a fiscal expansion by the core euro area economies on the periphery euro area economies.

\footnotetext{
${ }^{23}$ For example, if government spending goes up for 12 quarters and the nominal interest rate remains constant, then the impact multiplier is roughly 1.6 and has a peak value of about 2.3.
} 
Finally, we note that the early papers on the size of the government spending multiplier use log-linearized versions of DSGE models. For example, CER work with a linearized version of their model while CET work with a nonlinear version of the model. Significantly, there is now a literature which assesses the sensitivity of multiplier calculations to linear versus nonlinear solutions. See, for example, Christiano and Eichenbaum (2012), Boneva et al. (2016), ? and Linde and Trabandt (2017).

\section{Forward Guidance}

When the ZLB constraint on the nominal interest rate became binding, it was no longer possible to fight the recession using conventional monetary policy, i.e., lowering short-term interest rates. Monetary policymakers considered a variety of alternatives. Here, we focus on forward guidance as a policy option analyzed by Woodford and Eggertsson (2003) and Woodford (2012) in simple NK models. By forward guidance we mean that the monetary policymaker keeps the interest rate lower for longer than he or she ordinarily would. Campbell et al. (2012) refer to this form of monetary policy as Odyssean forward guidance.

As documented in Carlstrom et al. (2015), Odyssean forward guidance is implausibly powerful in standard DSGE models like CEE. Del Negro et al. (2012) refer to this phenomenon as the forward guidance puzzle. This puzzle has fueled an active debate. Carlstrom et al. (2015) and Kiley (2016) show that the magnitude of the forward guidance puzzle is substantially reduced in a sticky information (as opposed to a sticky price) model. Other responses to the forward guidance puzzle involve more fundamental changes, such as abandoning the representative agent framework. These changes are discussed in the next subsection. There is also a debate about the quantitative significance of the forward guidance puzzle. Campbell et al. (2017) estimate a medium-sized DSGE model using standard macroeconomic data, as well as Federal Funds rate futures data. They argue that the latter data push their estimation results in the direction of parameters for which there is no significant puzzle.

We conclude this section by returning to Stiglitz's critique of DSGE models. Stiglitz (2017, p. 7) writes:

"...the large DSGE models that account for some of the more realistic features of the macroeconomy can only be 'solved' for linear approximations and small shocks - precluding the big shocks that take us far away from the domain over which the linear approximation has validity."

Virtually every paper cited in this subsection (which are themselves a small subset of the relevant literature) is a counterexample to Stiglitz's claim. Stiglitz (2017, p. 1) also writes:

“...the inability of the DSGE model to...provide policy guidance on how to deal with the consequences [of the crisis], precipitated current dissatisfaction with the model."

The papers cited above and the associated literatures are clear counterexamples to Stiglitz's claim. Once again, Stiglitz (2017) gives no indication that he has read the literature that he is critiquing. 


\subsection{Heterogeneous Agent Models}

The primary channel by which monetary-policy induced interest rate changes affect consumption in the standard NK model is by causing the representative household to reallocate consumption over time. The representative household in the NK model has a borrowing limit, the so-called "natural borrowing limit'. But this limit is not binding. ${ }^{24}$ So the household's intertemporal consumption Euler equation is satisfied as a strict equality in all dates and states of nature. There is overwhelming empirical evidence against this perspective on how consumption decisions are made. First, there is a large literature which tests and rejects the representative consumer Euler equation using aggregate time series data. Second, there is a great deal of empirical micro evidence that a significant fraction of households face binding borrowing constraints.

Motivated by these observations, macroeconomists are exploring DSGE models where heterogeneous consumers face idiosyncratic shocks and binding borrowing constraints. While this is a young literature, it has already yielded important insights into policy issues, such as the efficacy of forward guidance and the channels by which government spending and conventional monetary policy affect the economy. Given space constraints, we cannot review this entire body of work here. Instead, we focus on two papers, Kaplan et al. (2017) (KMV) and McKay et al. (2016)(MNS), that convey the flavor of the literature. Both of these papers present DSGE models in which households have uninsurable, idiosyncratic income risk and face binding borrowing constraints. ${ }^{25}$

MNS focus their analysis on the forward guidance puzzle and show that it does not arise in their heterogeneous agent model. They argue that risk averse agents who anticipate the possibility of binding borrowing constraints in the future are less responsive to future interest rate changes than they would be in the absence of constraints. The absence of a forward guidance puzzle in the MNS model also reflects other, auxiliary, assumptions in the model. ? argue that incomplete markets, in conjunction with a particular departure from rational expectations offers a more robust resolution to the forward guidance puzzle. ${ }^{26}$

KMV focus their analysis on the mechanism by which conventional monetary policy shocks are transmitted through the economy. ${ }^{27}$ They stress that the mechanism in their model is very different from the one in the standard NK model. In their model, only a small number of agents satisfy their intertemporal Euler equation with equality. After a policy-induced fall in the interest rate, these agents intertemporally substitute towards current consumption. KMV refer to this rise in consumption as the direct effect of monetary policy. Borrowing constrained agents place heavy weight on current income in their consumption decisions. Increased spending by the agents who aren't borrowing constrained raises the income and the spending of borrowing-constrained agents. The rise in spending

\footnotetext{
${ }^{24}$ The natural debt limit is the level of debt such that it can only be repaid if leisure and consumption are held at zero forever. This constraint is never binding assuming that the marginal utility of consumption goes to infinity when consumption goes to zero.

${ }^{25}$ Important earlier papers in this literature include Oh and Reis (2012), Guerrieri and Lorenzoni (2017), McKay and Reis (2016), Gornemann et al. (2016) and Auclert (2015).

${ }^{26}$ The deviation from rational expectations that they argue for is what is referred to as $k$-level thinking.

${ }^{27}$ See also Ahn et al. (2017) who develop an efficient and easy-to-use computational method for solving a wide class of heterogeneous agent DSGE models with aggregate shocks. In addition, they provide an open source suite of codes that implement their algorithms in an easy-to-use toolbox.
} 
by borrowing-constrained agents is what KMV call the indirect effect of monetary policy. This indirect effect is very large and dominates the direct effect because it is associated with a mechanism which resembles the Keynesian multiplier in undergraduate textbooks.

We have focused our remarks on the implications of heterogeneous agent models for monetary policy. But it is clear that these models have important implications for the efficacy of fiscal policy as a tool for combatting business cycles. Most obviously, Ricardian equivalence fails when a significant fraction of agents face binding borrowing constraints. While there is a substantial amount of micro evidence that tax rebates affect consumer spending, there has been relatively little work studying these effects in heterogeneous agent DSGE models. ${ }^{28}$ The bulk of that work falls to the next generation of models.

We have emphasized work on incorporating heterogeneous households into DSGE models. But, there is also important work allowing for firm heterogeneity in DSGE models. Although this work is very promising, space considerations do not allow us to review it here. We refer the reader to Gilchrist et al. (2017) and Ottonello and Winberry (2017) for examples of work in this area.

We conclude this section by returning to Stiglitz (2017)'s critique that DSGE models do not include heterogeneous agents. He writes that:

“... DSGE models seem to take it as a religious tenet that consumption should be explained by a model of a representative agent maximizing his utility over an infinite lifetime without borrowing constraints." (Stiglitz, 2017, page 5).

It is hard to imagine a view more profoundly at variance with the cutting edge work on DSGE models by the leading young researchers in the field. Stiglitz (2017)'s paper shows no signs whatsoever that Stiglitz is aware of this work.

\section{How are DSGE Models Used in Policy Institutions?}

In this section we discuss how DSGE models are used in policy institutions. As a case study, we focus on the Board of Governors of the Federal Reserve System. We are guided in our discussion by Stanley Fischer's description of the policy-making process at the Federal Reserve Board (see Fischer (2017)).

Before the Federal Reserve system open market committee (FOMC) meets to make policy decisions, all participants are given copies of the so-called Tealbook. ${ }^{29}$ Tealbook A contains a summary and analysis of recent economic and financial developments in the United States and foreign economies as well as the Board staff's economic forecast. The staff also provides model-based simulations of a number of alternative scenarios highlighting upside and downside risks to the baseline forecast. Examples of such scenarios include a decline in the price of oil, a rise in the value of the dollar or wage growth that is stronger than the one built into the baseline projection. These scenarios are generated using one or more of the Board's macroeconomic models, including the DSGE models, SIGMA and EDO. ${ }^{30}$ This part of the

\footnotetext{
${ }^{28}$ See for example Johnson et al. (2006).

${ }^{29}$ The Tealbooks are available with a five year lag at https://www.federalreserve.gov/monetarypolicy/fomc_historical.htm.

${ }^{30}$ For a discussion of the SIGMA and the Estimated Dynamic Optimization (EDO) models, see Erceg et al. (2006) and https://www.federalreserve.gov/econres/edo-models-about.htm.
} 
Tealbook also contains estimates of future outcomes in which the Federal Reserve Board uses alternative policy rules as well model-based estimates of optimal policy. According to Fischer (2017), DSGE models play a central, though not exclusive, role in this process.

Tealbook B provides an analysis of specific policy options for the consideration of the FOMC at its meeting. According to Fischer (2017), "Typically, there are three policy alternatives - A, B, and $\mathrm{C}$ - ranging from dovish to hawkish, with a centrist one in between." The key point is that DSGE models, along with other approaches, are used to generate the quantitative implications of the specific policy alternatives considered. ${ }^{31}$ Dilettantes, who only point to the existence of different forces, have little to add to these quantitative assessments.

The Federal Reserve System is not the only policy institution that uses DSGE models. For example, the European Central Bank, the International Monetary Fund, Sveriges Riksbank, the Bank of Canada, and the Swiss National Bank all use such models in their policy process. ${ }^{32}$

We conclude this section with a fact: policy decisions are made by real people using their best judgement. Used wisely, DSGE models can improve and sharpen that judgement. In an ideal world, we will have both wise policymakers and insightful models. To paraphrase Fischer (2017)'s paraphrase of Samuelson on Solow: "We'd rather have Stanley Fischer than a DSGE model, but we'd rather have Stanley Fischer with a DSGE model than without one."

\section{Conclusion}

The DSGE enterprise is an organic process that involves the constant interaction of data and theory. Pre-crisis DSGE models had shortcomings that were highlighted by the financial crisis and its aftermath. Over the past 10 years, researchers have devoted themselves to improving the models, while preserving their core insights. We have emphasized the progress that has been made incorporating financial frictions and heterogeneity into DSGE models. Because of space considerations, we have not reviewed exciting work on deviations from conventional rational expectations. These deviations include $k$-level thinking, robust control, social learning, adaptive learning and relaxing the assumption of common knowledge. Frankly, we do not know which of these competing approaches, if any, will play a prominent role into the next generation of mainstream DSGE models. We do know that DSGE models will remain central to how macroeconomists think about aggregate phenomena and policy. There is simply no credible alternative to policy analysis in a world of competing economic forces.

\footnotetext{
${ }^{31}$ See Del Negro and Schorfheide (2013) for a detailed technical review of how DSGE are used in forecasting and how they fare in comparison with alternative forecasting techniques.

${ }^{32}$ For a review of the DSGE models used in the policy process at the ECB, see Smets et al. (2010). Carabenciov et al. (2013) describes a global model used for policy analysis at the International Monetary Fund (IMF), while Benes et al. (2014) describe MAPMOD, a model used at the IMF for the analysis of macroprudential policies. Adolfson et al. (2013) describe the RAMSES II model used for policy analysis at the Sveriges Riksbank. Dorich et al. (2013) describe ToTEM, the model used at the Bank of Canada for policy analysis and Alpanda et al. (2014) describe MP2, the model used at the Bank of Canada to analyze macroprudential policies. Rudolf and Zurlinden (2014) and Gerdrup et al. (2017) describe the model used at the Swiss National Bank and the Norges bank, respectively, for policy analysis.
} 


\section{References}

Adolfson, Malin, Stefan Laséen, Lawrence Christiano, Mathias Trabandt, and Karl Walentin, "Ramses II - Model Description," Sveriges Riksbank Occasional Paper Series 12, 2013.

Ahn, SeHyoun, Greg Kaplan, Benjamin Moll, Thomas Winberry, and Christian Wolf, "When Inequality Matters for Macro and Macro Matters for Inequality," Unpublished Manuscript, 2017.

Alpanda, Sami, Gino Cateau, and Césaire Meh, "A Policy Model to Analyze Macroprudential Regulations and Monetary Policy," Bank of Canada staff working paper 2014-6, 2014.

Altig, David, Lawrence J Christiano, Martin Eichenbaum, and Jesper Linde, "Firm-specific Capital, Nominal Rigidities and the Business Cycle," Review of Economic dynamics, 2011, 14 (2), 225-247.

Anderson, Eric, Sergio Rebelo, and Arlene Wong, "The Cyclicality of Gross Margins," Unpublished Manuscript, 2017.

Auclert, Adrien, "Monetary Policy and the Redistribution Channel," Unpublished Manuscript, 2015.

Backus, David K., Patrick J. Kehoe, and Finn E. Kydland, "International Real Business Cycles," Journal of Political Economy, 1992, 100 (4), 745-775.

Barro, Robert J, "Unanticipated Money, Output, and the Price Level in the United States," Journal of Political Economy, 1978, 86 (4), 549-580.

Benes, Jaromir, Michael Kumhof, and Douglas Laxton, "Financial Crises in DSGE Models : A Prototype Model," International Monetary Fund Working Paper No. 14/5\%, 2014.

Berger, David, Veronica Guerrieri, and Guido Lorenzoni, "House Prices and Consumer Spending," forthcoming, Review of Economic Studies, 2017.

Bernanke, Ben S., "The Macroeconomics of the Great Depression: A Comparative Approach," Journal of Money, Credit and Banking, 1995, 27 (1), 1-28.

_ , "Opening Remarks: Reflections on a Year of Crisis," Federal Reserve Bank of Kansas City's Annual Economic Symposium, Jackson Hole, Wyoming, August 21., 2009.

_, "Statement Before the Financial Crisis Inquiry Commission, Washington, D.C.," https://www.federalreserve.gov/newsevents/testimony/bernanke20100902a.pdf, 2010.

Bernanke, Ben S and Alan S. Blinder, "The Federal Funds Rate and the Channels of Monetary Transmission," American Economic Review, 1992, pp. 901-921. 
Bernanke, Ben S., Mark Gertler, and Simon Gilchrist, "The Financial Accelerator in a Quantitative Business Cycle Framework," Handbook of macroeconomics, 1999, 1, $1341-1393$.

Blanchard, Olivier, Christopher J Erceg, and Jesper Lindé, "Jump-starting the euro-area recovery: would a rise in core fiscal spending help the periphery?," NBER Macroeconomics Annual, 2017, 31 (1), 103-182.

Boldrin, Michele, Lawrence J Christiano, and Jonas DM Fisher, "Habit Persistence, Asset Returns, and the Business Cycle," American Economic Review, 2001, pp. 149-166.

Boneva, Lena Mareen, R. Anton Braun, and Yuichiro Waki, "Some unpleasant properties of loglinearized solutions when the nominal rate is zero," Journal of Monetary Economics, 2016, 84 (C), 216-232.

Brzoza-Brzezina, Michał and Marcin Kolasa, "Bayesian Evaluation of Dsge Models with Financial Frictions," Journal of Money, Credit and Banking, 2013, 45 (8), 1451-1476.

Calvo, Guillermo A., "Staggered Prices in a Utility-Maximizing Framework," Journal of Monetary Economics, 1983, 12 (3), 383-398.

Campbell, Jeffrey R., Charles L. Evans, Jonas DM Fisher, and Alejandro Justiniano, "Macroeconomic Effects of Federal Reserve Forward Guidance," Brookings Papers on Economic Activity, 2012, 2012 (1), 1-80.

Campbell, Jeffrey R, Jonas D M Fisher, Alejandro Justiniano, and Leonardo Melosi, "Forward guidance and macroeconomic outcomes since the financial crisis," NBER Macroeconomics Annual, 2017, 31 (1), 283-357.

Canova, Fabio and Luca Sala, "Back to Square One: Identification Issues in DSGE Models," Journal of Monetary Economics, 2009, 56 (4), 431-449.

Carabenciov, Ioan, Charles Freedman, Roberto Garcia-Saltos, Douglas Laxton, Ondra Kamenik, and Petar Manchev, "GPM6 : The Global Projection Model with 6 Regions," IMF Working Paper no. 13/87, 2013.

Carlstrom, Charles T and Timothy S. Fuerst, "Agency Costs, Net Worth, and Business Fluctuations: A Computable General Equilibrium Analysis," American Economic Review, 1997, pp. 893-910.

Carlstrom, Charles T., Timothy S. Fuerst, and Matthias Paustian, "Inflation and Output in New Keynesian Models with a Transient Interest Rate Peg," Journal of Monetary Economics, 2015, 76, 230-243.

Carroll, Christopher D, Jody Overland, and David N Weil, "Comparison Utility in a Growth Model," Journal of Economic Growth, 1997, 2 (4), 339-367.

_ , _ , and _ , "Saving and Growth with Habit Formation," American Economic Review, 2000, pp. 341-355. 
Chari, V. V., Lawrence J. Christiano, and Martin Eichenbaum, "Inside Money, Outside Money, and Short-term Interest Rates," Journal of Money, Credit 83 Banking, 1995, 27 (4), 1354-1402.

Chernozhukov, Victor and Han Hong, "An MCMC approach to classical estimation," Journal of Econometrics, 2003, 115 (2), 293-346.

Chetty, Raj, Adam Guren, Day Manoli, and Andrea Weber, "Are Micro and Macro Labor Supply Elasticities Consistent? a Review of Evidence on the Intensive and Extensive Margins," American Economic Review, 2011, 101 (3), 471-475.

Christiano, Lawrence J. and Joshua M. Davis, "Two Flaws In Business Cycle Accounting," Working Paper 12647, National Bureau of Economic Research October 2006.

- and Martin Eichenbaum, "Notes on linear approximations, equilibrium multiplicity and e-learnability in the analysis of the zero lower bound," Working Paper, 2012.

_, _, and Charles L. Evans, "The Effects of Monetary Policy Shocks: Evidence from the Flow of Funds," The Review of Economics and Statistics, 1996, 78(1), 16-34.

_ , _, and _ , "Monetary Policy Shocks: What Have We Learned and to What End?," Handbook of Macroeconomics, 1999, 1 (A), 65-148.

_ , , , and _ , "Nominal Rigidities and the Dynamic Effects of a Shock to Monetary Policy," Journal of Political Economy, 2005, 113 (1), 1-45.

- , Martin S. Eichenbaum, and Mathias Trabandt, "Unemployment and Business Cycles," Econometrica, 2016, 84 (4), 1523-1569.

_, Mathias Trabandt, and Karl Walentin, "DSGE Models for Monetary Policy Analysis," Handbook of Monetary Economics, 2010, 3, 285-367.

Christiano, Lawrence J, Roberto Motto, and Massimo Rostagno, "Risk Shocks," The American Economic Review, 2014, 104 (1), 27-65.

Christiano, Lawrence, Martin Eichenbaum, and Sergio Rebelo, "When is the Government Spending Multiplier Large?," Journal of Political Economy, 2011, (February).

_ , Roberto Motto, and Massimo Rostagno, "The Great Depression and the FriedmanSchwartz Hypothesis," Journal of Money, Credit and Banking, 2003, 35 (6), 1119-1197.

Clarida, Richard, Jordi Galí, and Mark Gertler, "The Science of Monetary Policy: A New Keynesian Perspective," Journal of Economic Literature, 1999, 37, 1661-1707.

Coenen, Günter, Christopher J Erceg, Charles Freedman, Davide Furceri, Michael Kumhof, René Lalonde, Douglas Laxton, Jesper Lindé, Annabelle Mourougane, Dirk Muir et al., "Effects of fiscal stimulus in structural," American Economic Journal: Macroeconomics, 2012, 4 (1), 22-68. 
Cole, Harold L and Timothy J Kehoe, "Self-fulfilling debt crises," The Review of Economic Studies, 2000, 67 (1), 91-116.

Comin, Diego and Mark Gertler, "Medium-Term Business Cycles," American Economic Review, June 2006, 96 (3), 523-551.

Constantinides, George M., "Habit Formation: A Resolution of the Equity Premium Puzzle," Journal of Political Economy, 1990, 98 (3), 519-543.

Cooley, Thomas F and Gary D Hansen, "The Inflation Tax in a Real Business Cycle Model," The American Economic Review, 1989, pp. 733-748.

Dorich, José, Michael K. Johnston, Rhys R. Mendes, Stephen Murchison, and Yang Zhang, "ToTEM II: An Updated Version of the Bank of Canada's Quarterly Projection Model," Bank of Canada technical report no. 100, 2013.

Dunn, Kenneth B. and Kenneth J. Singleton, "Modeling the term structure of interest rates under non-separable utility and durability of goods," Journal of Financial Economics, 1986, 17 (1), 27 - 55.

Eberly, Janice, Sergio Rebelo, and Nicolas Vincent, "What Explains the Laggedinvestment Effect?," Journal of Monetary Economics, 2012, 59 (4), 370-380.

Eichenbaum, Martin and Lars Peter Hansen, "Estimating Models with Intertemporal Substitution Using Aggregate Time Series Data," Journal of Business 6 Economic Statistics, 1990, 8 (1), 53-69.

_ , Lars P Hansen, and S.F. Richard, "Aggregation, Durable Goods and Nonseparable Preferences in an Equilibrium Asset Pricing Model," 1982.

_ , Nir Jaimovich, and Sergio Rebelo, "Reference prices, costs, and nominal rigidities," American Economic Review, 2011, 101 (1), 234-262.

Eichenbaum, Martin S. and Lars Peter Hansen, "Estimating Models with Intertemporal Substitution Using Aggregate Time Series Data," Journal of Business and Economic Statistics, American Statistical Association, 1990, 8 (1), 53-69.

Erceg, Christopher and Jesper Lindé, "Is there a fiscal free lunch in a liquidity trap?," Journal of the European Economic Association, 2014, 12 (1), 73-107.

_, Luca Guerriei, and Christopher Gust, "SIGMA: A new open economy model for policy analysis," International Journal of Central Banking, 2006, 2 (1).

Fernández-Villaverde, Jesús, Juan Francisco Rubio-Ramirez, and Frank Schorfheide, "Solution and estimation methods for DSGE models," Handbook of Macroeconomics, 2016, 2, 527-724.

Fischer, Stanley, "'Long-term contracting, sticky prices, and monetary policy'. A comment," Journal of Monetary Economics, 1977, 3 (3), 317-323. 
_ , "Speech at the Warwick Economics Summit, Coventry, United Kingdom, 11 February," http://www.bis.org/review/r170214a.htm, 2017.

Friedman, Milton, "The role of monetary policy," American Economic Review, 1968, 58 (1), 1-17.

Galí, Jordi, Monetary Policy, Inflation, and the Business Cycle: An Introduction to the New Keynesian Framework and Its Applications, Princeton University Press, 2015.

_ , J David López-Salido, and Javier Vallés, "Understanding the Effects of Government Spending on Consumption," Journal of the European Economic Association, 2007, 5 (1), $227-270$.

Gerdrup, Karsten R., Erling Motzfeldt Kravik, Kenneth Sæterhagen Paulsen, and Ørjan Robstad, "Documentation of NEMO - Norges Bank's core model for monetary policy analysis and forecasting," Norges Bank, Staff Memo no. 8, 2017.

Gertler, Mark and Nobuhiro Kiyotaki, "Banking, liquidity, and bank runs in an infinite horizon economy," American Economic Review, 2015, 105 (7), 2011-2043.

_, _, and Andrea Prestipino, "Wholesale banking and bank runs in macroeconomic modeling of financial crises," Handbook of Macroeconomics, 2016, 2, 1345-1425.

Gilchrist, Simon, Raphael Schoenle, Jae Sim, and Egon Zakrajšek, "Inflation Dy-

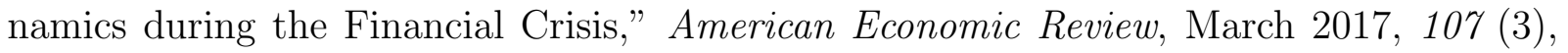
$785-823$.

Gornemann, Nils, Keith Kuester, and Makoto Nakajima, "Doves for the Rich, Hawks for the Poor? Distributional Consequences of Monetary Policy," 2016.

Gremel, Christina M., Jessica H. Chancey, Brady K. Atwood, Guoxiang Luo, Rachael Neve, Charu Ramakrishnan, Karl Deisseroth, David M. Lovinger, and Rui M. Costa, "Endocannabinoid Modulation of Orbitostriatal Circuits Gates Habit Formation," Neuron, 2016, 90 (6), 1312 - 1324.

Guerrieri, Veronica and Guido Lorenzoni, "Credit Crises, Precautionary Savings, and the Liquidity Trap," Quarterly Journal of Economics, August 2017, 132 (3), 1427-1467.

Gürkaynak, Refet, Brian Sack, and Eric Swanson, "The Sensitivity of Long-Term Interest Rates to Economic News: Evidence and Implications for Macroeconomic Models," American Economic Review, March 2005, 95 (1), 425-436.

Gust, Christopher, Edward Herbst, David López-Salido, and Matthew E. Smith, "The Empirical Implications of the Interest-Rate Lower Bound," American Economic Review, July 2017, 107 (7), 1971-2006.

Hansen, Lars Peter, "Large Sample Properties of Generalized Method of Moments Estimators," Econometrica, 1982, 50 (4), 1029-1054. 
Hofmann, Boris, Gert Peersman, and Roland Straub, "Time variation in US wage dynamics," Journal of Monetary Economics, 2012, 59 (8), 769-783.

Hume, David, "Of Money," Part II, Essay III.7, in Essays, Moral, Political, and Literary, http://www.econlib.org/library/LFBooks/Hume/hmMPL26.html, 1742.

Iacoviello, Matteo, "House Prices, Borrowing Constraints, and Monetary Policy in the Business Cycle," American Economic Review, 2005, 95 (3), 739-764.

- and Stefano Neri, "Housing Market Spillovers: Evidence from an Estimated DSGE Model," American Economic Journal: Macroeconomics, 2010, 2 (2), 125-164.

Johnson, David S., Jonathan A. Parker, and Nicholas S. Souleles, "Household Expenditure and the Income Tax Rebates of 2001," American Economic Review, December 2006, 96 (5), 1589-1610.

Kaplan, Greg, Benjamin Moll, and Giovanni L Violante, "Monetary policy according to HANK," Unpublished Manuscript, 2017.

Kiley, Michael, "Policy Paradoxes in the New-Keynesian Model," Review of Economic Dynamics, July 2016, 21, 1-15.

King, Robert G and Sergio T Rebelo, "Resuscitating Real Business Cycles," Handbook of Macroeconomics, 1999, 1, 927-1007.

Kiyotaki, Nobuhiro and John Moore, "Credit Cycles," Journal of Political Economy, 1997, 105 (2), 211-248.

Kocherlakota, Narayana R, "Creating Business Cycles Through Credit Constraints," Federal Reserve Bank of Minneapolis Quarterly Review, 2000, 24 (3), 2-10.

Korinek, Anton, "Thoughts on DSGE Macroeconomics: Matching the Moment, But Missing the Point?," Working Paper, 2017.

Krugman, Paul R, "It's baaack: Japan's slump and the return of the liquidity trap," Brookings Papers on Economic Activity, 1998, (2), 137-205.

Kuttner, Kenneth, "Monetary Policy Surprises and Interest Rates: Evidence from the Fed Funds Futures Market," Journal of Monetary Economics, June 2001, 47 (3), 523-544.

Kydland, Finn E. and Edward C. Prescott, "Time to Build and Aggregate Fluctuations," Econometrica, 1982, pp. 1345-1370.

_ and _ , "Hours and Employment Variation in Business-Cycle Theory," Economic Theory, 1991, pp. 107-134.

Linde, Jesper and Mathias Trabandt, "Should We Use Linearized Models To Calculate Fiscal Multipliers?," 2017. 
_ , Frank Smets, and Rafael Wouters, "Challenges for Central Bank Models," Handbook of Macroeconomics, 2016, 2B, 2185-2256.

Liu, Zheng, Pengfei Wang, and Tao Zha, "Land-Price Dynamics and Macroeconomic Fluctuations," Econometrica, 2013, 81 (3), 1147-1184.

Long, John B. and Charles I. Plosser, "Real Business Cycles," Journal of political Economy, 1983, 91 (1), 39-69.

Lucas, Robert E., "Methods and Problems in Business Cycle Theory," Journal of Money, Credit and banking, 1980, 12 (4), 696-715.

- and Edward C. Prescott, "Investment Under Uncertainty," Econometrica, 1971, 39 (5), 659-681.

Lucca, David Olivier, "Essays in Investment and Macroeconomics," Phd Dissertation, Northwestern University, Department of Economics, 2006.

Matsuyama, Kiminori, "A Learning Effect Model of Investment: An Alternative Interpretation of Tobin's Q'," Manuscript, Northwestern University, 1984.

McKay, Alisdair and Ricardo Reis, "The Role of Automatic Stabilizers in the U.S. Business Cycle," Econometrica, 2016, 84 (1), 141-194.

_ , Emi Nakamura, and Jón Steinsson, "The Power of Forward Guidance Revisited," American Economic Review, 2016, 106 (10), 3133-3158.

Mertens, Karel and Morten O Ravn, "The Dynamic Effects of Personal and Corporate Income Tax Changes in the United States," American Economic Review, 2013, 103 (4), $1212-47$.

Mussa, Michael, "Nominal exchange rate regimes and the behavior of real exchange rates: Evidence and implications," Carnegie-Rochester Conference series on public policy, 1986, 25.

Nakamura, Emi and Jon Steinsson, "Five Facts About Prices: A Reevaluation of Menu Cost Models," Quarterly Journal of Economics, 2008, 123 (4), 1415-1464.

Negro, Marco Del and Frank Schorfheide, "DSGE Model-Based Forecasting," Allan Timmermann, Graham Elliott, editors, Handbook of Economic Forecasting, North Holland, 2013.

Negro, Maro Del, Marc Giannoni, and Christina Patterson, "The Forward Guidance Puzzle," Federal Reserve Bank of New York Staff Report, 2012, (574).

Oh, Hyunseung and Ricardo Reis, "Targeted transfers and the fiscal response to the great recession," Journal of Monetary Economics, 2012, 59, 50 - 64.

Ottonello, Pablo and Thomas Winberry, "Financial Heterogeneity and the Investment Channel of Monetary Policy," Unpublished Manuscript, 2017. 
Ramey, Valerie A., "Macroeconomic Shocks and Their Propagation," Handbook of Macroeconomics, 2016, 2, 71-162.

Rotemberg, Julio J. and Michael Woodford, "Markups and the Business Cycle," NBER Macroeconomics Annual 1991, MIT Press, 1991, 6, 63-140.

Rudolf, Barbara and Mathias Zurlinden, "A compact open economy DSGE model for Switzerland," Economic Studies 2014-08, Swiss National Bank, 2014.

Sims, Christopher A., "Are Forecasting Models Usable for Policy Analysis?," Federal Reserve Bank of Minneapolis Quarterly Review, 1986, 10 (1), 2-16.

Smets, Frank and Rafael Wouters, "An Estimated Dynamic Stochastic General Equilibrium Model of the Euro Area," Journal of the European Economic Association, 2003, 1 (5), 1123-1175.

_ and _, "Shocks and Firctions in US Business Cycle: A Bayesian DSGE Approach," American Economic Review, 2007, 97, 586-606.

_, Kai Christoffel, Günter Coenen, Roberto Motto, and Massimo Rostagno, "DSGE models and their use at the ECB," SERIEs, Mar 2010, 1 (1), 51-65.

Stiglitz, Joseph E, "Where Modern Macroeconomics Went Wrong," National Bureau of Economic Research Working Paper Series, 2017.

Taylor, John B., "Aggregate Dynamics and Staggered Contracts," Journal of Political economy, 1980, 88 (1), 1-23.

- and Harald Uhlig, "editors, Solving Nonlinear Rational Expectations Models," Journal of Business and Economic Statistics, 1990, 8 (1), 1-51.

Topel, Robert and Sherwin Rosen, "Housing investment in the United States," Journal of Political Economy, 1988, 96 (4), 718-740.

Wan, Eric A. and Rudolph van der Merwe, "The Unscented Kalman Filter," Kalman Filering and Neural Networks, John Wiley and Sons, Inc., edited by Simon Haykin, 2001.

Woodford, Michael, Interest and Prices: Foundations of a Theory of Monetary Policy, Princeton University Press, 2003.

_ , "Methods of Policy Accommodation at the Interest-rate Lower Bound," ProceedingsEconomic Policy Symposium-Jackson Hole, Federal Reserve Bank of Kansas City, 2012, pp. 185-288.

- and Gauti Eggertsson, "The Zero Bound on Interest Rates and Optimal Monetary Policy," Brookings Papers on Economic Activity, 2003, (1).

Yun, Tack, "Nominal Price Rigidity, Money Supply Endogeneity, and Business Cycles," Journal of Monetary Economics, 1996, 37 (2), 345-370. 